\title{
HOSPITALIZATION TIME AFTER OPEN APPENDECTOMY BY THREE DIFFERENT SURGICAL TECHNIQUES
}

\author{
Tempo de internação após apendicectomia aberta por três técnicas cirúrgicas diferentes
}

\author{
Agláia Moreira Garcia XIMENES, Fernando Salvo Torres MELLO, Zailton Bezerra de LIMA-JÚNIOR, \\ Cícero Faustino FERREIRA, Amanda Dantas Ferreira CAVALCANTI, Adalberto Vieira DIAS-FILHO
}

From Liga Acadêmica de Cirurgia e Trauma da Universidade Federal da Paraíba, Hospital General Edson Ramalho (Surgery and Trauma Academic League, Federal University of Paraíba, General Edson Ramalho Hospital), João Pessoa, PB, Brazil.

HEADINGS - Appendectomy. Appendicitis. Length of stay.
ABSTRACT - Background: The choice of surgical technique to approach the appendicular stump depends mostly on skill and personal preference of the surgeon or on the protocol used in the service, and the influence of this choice in hospitalization time is not evaluated. Aim: To evaluate the relation between surgical technique and postoperative hospitalization time in patients presenting with acute appendicitis. Methods: Retrospective analysis of 180 patients who underwent open appendectomy. These where divided into three groups according to surgical technique: conventional appendectomy (simple ligation of the stump), tobacco pouch suture and Parker-Kerr suture. Data where crossed with hospitalization time (until three days, from four to six days and over seven days). Results: A hundred and eighty patients with age from 15 to 85 years where included. From these, 95 underwent conventional technique, had an average hospitalization time of 3,9 days and seven had complications (surgical site infection, seroma, suture dehiscence and evisceration). In 67 patients, tobacco pouch suture was chosen and had average hospitalization time of 3,7 days and two complications (infection and seroma). In 18 Parker-Kerr suture was made, with average hospitalization time of 2,6 days, with no complication. Contingency coefficient between the variables hospitalization time and technique was 0,255 and Cramér's $V$ was 0,186 . Conclusion: There was tendency to larger hospitalization time and larger number of complications in conventional appendectomy, whereas in patients where Parker-Kerr suture was performed, hospitalization time was significantly smaller.

\section{CorrespondEnce:}

Agláia Moreira Garcia Ximenes

E-mail: aglaiamoreiragx@yahoo.com.br

Financial source: none

Conflicts of interest: none

Received for publication: 04/12/2013 Accepted for publication: 11/03/2014

\section{DESCRTORES - Apendicectomia.} Apendicite. Tempo de internação.
RESUMO - Racional: A escolha da técnica de tratamento do coto apendicular na maioria das vezes depende da habilidade e preferência do cirurgião ou do protocolo adotado no serviço, e não se avalia a influência desta escolha no tempo de internação. Objetivo: Avaliar a relação entre a técnica cirúrgica e o tempo de permanência hospitalar pós-operatória em pacientes com apendicite aguda. Métodos: Análise retrospectiva dos pacientes submetidos à apendicectomia aberta. Foram avaliados três grupos de acordo com a técnica cirúrgica: convencional (ligadura simples do coto apendicular), sutura em bolsa de tabaco e sutura a Parker-Kerr. Os dados foram cruzados com intervalos de tempo de internação estipulados aleatoriamente (até três dias, de quatro a seis dias, e sete ou mais dias). Resultados: Foram avaliados 180 pacientes entre 15 e 85 anos. Destes, 95 foram submetidos à técnica convencional com média de 3,9 dias de internação e sete apresentaram complicações (infecção de ferida operatória, deiscência de sutura, evisceração e seroma). Em 67 pacientes foi feita sutura em bolsa de tabaco e a média de internação foi de 3,7 dias, com dois casos de complicação (infecção de ferida operatória). Em 18 foi feita a técnica de Parker-Kerr, e o tempo médio foi de 2,6 dias de internação, sem complicações descritas. O coeficiente de contingência entre as variáveis tempo de internação e técnica foi de 0,255 e o coeficiente $V$ de Cramér foi de 0,186. Conclusão: Houve tendência ao maior tempo de recuperação e maior número de complicações na apendicectomia convencional, enquanto nos pacientes com apendicectomia à Parker-Kerr o tempo de internamento foi significativamente menor.

A cute appendicitis figures among the diseases most frequently requires emergency surgical treatment. The first appendectomy was registered in the $18^{\text {th }}$ century, during which Claudius Amyand ${ }^{1,4}$ published his studies about acute appendicitis and the usage of sutures in gastrointestinal viscera. Since then, many techniques have been developed $7,12,1,1,18,25$, the most common being the simple ligation of the appendiceal stump and the burial of the stump associated or not with ligation 2,5 .

Classical appendectomy consists in the excision of the appendix and simple ligation in the basis of the appendiceal stump. The tobacco pouch surgical technique is made through burial of the stump, with or without ligation. It is also possible to make the suture in the basis of the stump associated with the Parker-Kerr technique, in which the suture line is overlapped with the outer intestinal wall122,25,26.

The choice of the technique for management of the stump depends mostly in the surgeons preference or due to the protocol adoption by the hospital, $8,13,17,23$. When the length of stay in the hospital is evaluated, the importance of surgical technique is 
surpassed by other determinant factors, such as pre-operative duration of illness, response to antibiotics and the presence of comorbities.

Another factor that can determine the choice of technique is the amount of time necessary for its completion: in patients with a ruptured appendix, compromised clinical status and hemodynamic instability or conditions that do not permit a long operation - such as pregnancy -, simple ligation can be chosen for being faster, reducing operating time.

Studies that evaluate the influence of technique over clinical results are scarce. Most of them are retrospective, and there are few clinical trials on this subjetc $c^{7,11}$. Among those that emphasize surgical technique, medical literature compare only two techniques for the treatment of acute apendicitis ${ }^{2,3,5,7,7,9,11,13,16,17}$

In addition to that, they compare only the two main techniques: simple ligation, also called classical appendectomy, and the burial of the appendiceal stump (tobacco pouch), with or without ligation 9,11,13,17.

An experimental study in rabbits evaluating these two techniques has shown that macroscopically there are no significant differences; though under microscopic analysis, simple ligation was able to preserve the integrity of the caecum mucous layer and caused less fibrosis ${ }^{5}$. On the other hand, randomized, randomized trials in humans were not able to show statistically significant difference among these two techniques ${ }^{5}$. Some randomized trials in humans show superiority of simple ligation (due to its faster time of execution and diminished capacity to cause adherences and anatomical deformities), though without statistically significant results $5,7,11$. Other studies concluded that these techniques are similar and lead to the same clinical results ${ }^{2,16}$.

Recently, as more attention is directed towards laparoscopic procedures, studies have compared appendectomy through this via of access to the abdominal cavity with conventional laparotomy ${ }^{15,23,24}$, or even with umbilical laparotomy ${ }^{9}$. However, in studies the approach of the appendiceal stump is seldom evaluated ${ }^{21}$.

The aim of this study was to correlate the surgical technique for management of the appendiceal stump with post-operative length of stay, also evaluating complications in patients who underwent laparotomic appendectomy by three different techniques.

\section{METHODS}

A retrospective analysis was made in files of all patients who underwent appendectomy from January $1^{\text {st }}$ to December 31 th, 2012 , in General Edson Ramalho Hospital, João Pessoa, PB, Brazil. Inclusion criteria were: patient file containing detailed data, legible operation description and pathology report confirming the diagnosis of acute appendicitis. All files in which the surgical technique was not adequately described, or the handwriting lead to misreading were excluded. Patients who were pregnant when affected by appendicitis were also excluded.

As the study aimed to collect data from all patients operated during a year and the study design, is was not necessary to calculate the size of the sample.

Patients were divided into three groups according to appendectomy surgical technique: conventional/classic, tobacco pouch and Parker-Kerr suture. Then, they were also divided according to length of stay (until three days, four to six days and seven or more days). The occurrence of complications requiring transference to intensive care in the post-operative period was also analyzed.

After calculation frequencies and central tendency measures, a cross-tabulation analysis was made for the variables technique and length of stay using a contingency table. For such procedure, the Chi-square test was performed, followed by the Crammèr's $V$ test, and contingency and uncertainty coefficients were calculated. All these are standard tests for comparison of nominal variables. Statistical analysis was performed using IBM SPSS and Microsoft Excel 2010.

\section{RESULTS}

Based in the inclusion criteria, 180 patients were selected, from those, 113 (62,8\%) were males and 67 (37,2\%) females. Regarding age, $58,9 \%$ were up to 30 years old and $83,9 \%$ were up to 40 . Age extremes were 15 and 85 years. Pathology reports were not found in files of nine patients operated in 2012, and therefore they were not included in the study. Only one patient was pregnant when the acute appendicitis diagnose was confirmed. For this reason she was transferred immediately to intensive care unit after surgery and was not included in the sample.

Convention appendectomy technique was performed in $52,8 \%$ of the patients, who had average length of stay of 3,9 days. In seven of them complications occurred and transference to intensive care unit was necessary. Patients in which tobacco pouch technique was performed $(37,2 \%)$, had an average length of stay of 3,7 days, and two of them went to intensive care unit. In patients in which Parker-Kerr suture was chosen (10\%), the average length of stay was 2,6 days, and none presented complications. Death was the outcome of none of the selected patients.

Length of stay was up to three days in $64,4 \%$ of the patients, four to six days in $27,8 \%$ of them and seven or more days in 7,8\%. Minimum length of stay was one day (one patient in which tobacco pouch technique was performed), and maximum was 19 days (one patient in which conventional technique was performed and transference to intensive care unit was necessary).

When cross tabulation analysis was performed between the variables technique and length of stay, Crammèr's V was 0,186 and the contingency coefficient was 0,255 . Considering that these coefficients have maximum value of 1 (which indicate total correlation between variables), it is observed that this values show a discreet correlation, though existing, between the variables. Three variants of the uncertainty coefficient were calculated: symmetric $(0,044)$, technique dependent $(0,042)$ and length of stay dependent $(0,044)$.

These results points towards a slightly enhanced chance of a patient in the conventional technique group having a larger hospitalization time (seven or more days), and also point to a slightly higher chance of patient with the ParkerKerr suture have lower length of stay (three or less days).

\section{DISCUSSION}

Acute appendicitis is a condition that can be diagnosed mainly by its clinical features $8,10,19,20$; however, in this sample only $4 \%$ had a purely clinical diagnosis. In $19,1 \%$ of them only one complementary exam was necessary (white blood cells count or ultrasound). In all the other patients, diagnosis was confirmed using two or more exams. In $86,9 \%$ of the patients a white blood cell count associated with other laboratorial exams was necessary and in $60,6 \%$ of them ultrasound was required.

Patients sample size obtained in the interval of time considered was similar to that calculated in national and international clinical trials studying the same clinical subject ${ }^{2,9,11,17}$. The fact that acute appendicitis occurs mainly in young males is well established in medical literature ${ }^{8,10}$, and the sample included in this study showed the same pattern, considering that the number of males was almost two times 
the number of females, and the majority of the patients were 30 years of age or less.

Considering that in the hospital were this study was performed the surgical technique is a surgeons choice, the group size varied. This shows that most surgeons prefer the conventional technique due to the shorter amount of time necessary to its completion, which is adequate to an institution where the daily number of surgeries is large.

Acute appendicitis is a disease with a low mortality rate, and agreeing with literature, there were no cases of death in the group of patients selected.

Regarding post-operative length of stay, Neves et al ${ }^{16}$ found a higher average time when the chosen technique was the burial of the appendiceal stump compared to conventional technique. This study showed a contrary result to these findings, though the difference in average time was only 0,2 days.

Although the fact that for patients in which Parker-Kerr suture was performed, length of hospital stay was smaller than in the other techniques, it was not possible to compare this finding with previous studies, once that there is a tendency to consider only the two most common techniques (simple ligation and tobacco pouch) in the consulted publications.

Studies with smaller series which compared only these two techniques varied ${ }^{7,11,13}$, some of them finding larger length of stay with the conventional technique, and some with the tobacco pouch. Nevertheless, in these studies the difference was not statistically significant. The same occurred considering the number of post-operative complications and need of intensive care.

No clinical randomized trials were found evaluating the same variables as this study (hospitalization time and complications rate) in patients who underwent appendectomy with the Parker-Kerr suture.

Statistical analysis of the contingencies showed that there is a correlation between variables and that the tendency to a higher length of stay when the conventional technique is used is not random. However, this association is discrete considering the small value of the Crammèr's $V$ and the contingency coefficient.

In a recent study published by Dhupar et $\mathrm{al}^{6}$, with a sample of 435 patients, established by logistic regression that age is a determinant factor of complicated appendicitis and higher length of hospitalization. This study could not confirm this fact, given that in the conventional and tobacco pouch techniques groups the age average was the same (31 years) and in those of the Parker-Kerr technique the age average was 29 years.

\section{CONCLUSION}

There was a tendency to a larger time of recovery and hospitalization in conventional appendectomy, while in patients for whom the Parker-Kerr Suture was chosen the duration of hospitalization was significantly reduced.

\section{REFERENCES}

1. Amyand C. Of an Inguinal Rupture, with a Pin in the Appendix Coeci, Incrusted with Stone; And Some Observations on wounds in the guts. Philos Trans R Soc Lond 1736; 39: 329-42

2. Andrade JI, Hsien CT, Martins Junior A, Ceneviva R. Apendicite aguda: estudo prospectivo de 90 casos, com especial referência a comparação entre duas técnicas de tratamento do coto apendicular. Rev Col Bras Cir 1989; 16(1): 3-6
3. Andrade JI, Sandoval EGB, Gomes CAP, Scarpelini S, Seneviva R. Apendicectomia: tratamento do coto apendicular por ligadura e por sepultamento. Rev Col Bras Cir 1996; 11(6): 314-9.

4. Barcat, JA. Sobre la apendicitis aguda: Amyand, Fitz, y unos pocos más. Medicina (B. Aires) vol.70 no.6 Ciudad Autónoma de Buenos Aires nov./dic. 2010. Editorial.

5. Cabral Junior, AS et al . Apendicectomia pelas técnicas de ligadura simples e de sepultamento sem ligadura do coto apendicular: estudo comparativo em coelhos Rev Col Bras Cir 2001; 28( 6)

6. Dhupar R, Evankovich J, Ochoa JB, Vargas LG, Hughes SJ. Outcomes of operative management of appendicitis. Surg Infect (Larchmt). 2012 Jun;13(3):141-6.

7. Engström L, Fenyö G. Appendicectomy: assessment of stump invagination versus simple ligation: a prospective, randomized trial. Br J Surg. 1985 Dec;72(12):971-2.

8. Franzon O, Piccoli MC, Neves TT, Volpato MG. Apendicite aguda: análise institucional no manejo peri-operatório. ABCD Arq Bras Cir Dig 2009;22(2):72-5.

9. Frutos MD, Abrisqueta J, Lujan J, Abellan I, Parrilla P. Randomized prospective study to compare laparoscopic appendectomy versus umbilical single-incision appendectomy. Ann Surg. 2013 Mar;257(3):413-8.

10. Goulart RN, Silvério GS, Moreira MB, Franzon O. Achados principais de exames laboratoriais no diagnóstico de apendicite aguda: uma avaliação prospectiva. ABCD Arq Bras Cir Dig. 2012;25(2):88-90.

11. Jacobs PP, Koeyers GF, Bruyninckx CM. Simple ligation superior toinversion of the appendiceal stump; a prospective randomized study.Ned Tijdschr Geneeskd. 1992 May 23;136(21):1020-3.

12. Kingsley DPE. Some observations on appendicectomy with particular reference to technique. Br J Surg 1969; 56: 491-6

13. Lavonius MI, Liesjärvi S, Niskanen RO, Ristkari SK, Korkala O, Mokka RE. Simple ligation vs stump inversion in appendicectomy. Ann Chir Gynaecol 1996; 85(3): 222-4.

14. Maier WP, Rosemond GP. A late complication of inversion of the appendiceal stump. Am J Surg. 1969 Sep;118(3):467-8.

15. Navarini D, Valiati AA, Rodrigues RR, Aita LN, Migliavaca A, Guimarães JR. Apendicectomia Laparoscópica Versus Aberta: Análise Retrospectiva. Rev HCPA 2009;29(2):115-119

16. Neves, LJVA et al. Ligadura simples ou ligadura com confecção de bolsa e sepultamento para tratamento do coto apendicular: estudo comparativo prospectivo randomizado. ABCD Arq Bras Cir Dig 2011;24(1): 15-19

17. Novelletto, ST; El Haje, A A; Kruel, NF; Franzon, O; Susuki, H; Andrian, AC. Estudo comparativo do tratamento do coto apendicular por ligadura e por sepultamento. Rev Bras Cir 1996; 86(6):293-6.

18. Ochsner A, Lilly G. The technique of appendicectomy: With particular reference to the treatment of the appendiceal stump. Surgery 1937;2: 532-54.

19. Pittman-Waller VA, Myers JG, Stewart RM, Dent DL, Page CP, Gray GA, Pruitt BA Jr, Root HD. Appendicitis: why so complicated? Analysis of 5755 consecutive appendectomies. Am Surg. 2000 Jun;66(6):548-54.

20. Robaina HF, Sánchez HF, Izquierdo OM, Camejo SYG. Apendicitis aguda: estudio estadístico de 214 casos operados. Rev Cub Invest Bioméd 2007; 26 (3).

21. Sauerland S, Kazemier G. Appendix stump closure during laparoscopic appendectomy (Protocol). Cochrane Database of Systematic Reviews 2007, Issue 2. Art. No.: CD006437. DOI: 10.1002/14651858.CD006437.

22. Sinha AP. Appendicectomy: an assessment of the advisability of stump invagination. Br J Surg 1977; 64(7): 499-500.

23. Sozutek A, Colak T, Dirlik M, Ocal K, Turkmenoglu O, Dag A. A Prospective Randomized Comparison of Single-port Laparoscopic Procedure With Open and Standard 3-port Laparoscopic Procedures in the Treatment of Acute Appendicitis. Surg Laparosc Endosc Percutan Tech. 2013 Feb;23(1):74-8.

24. Suttie SA, Seth S, Driver CP, Mahomed AA. Outcome after intra- and extra-corporeal laparoscopic appendectomy techniques. Surgical Endoscopy And Other Interventional Techniques. July 2004, 18(7), 1123-1125.

25. Watters DA, Walker MA, Abernethy BC. The appendix stump: should it be invaginated? Ann R Coll Surg Engl. 1984 Mar;66(2):92-3

26. Yeager, G. The Appendiceal Stump. Annals et Surgery November 1947. 126(5) , 814-19. 